\title{
The Effect of Hydrogen Peroxide on Sarco/Endoplasmic and Plasma Membrane Calcium ATPase Gene Expression in Cultured Human Lens Epithelial Cells
}

\author{
M.J. Marian ${ }^{1}$, P. Mukhopadhyay ${ }^{2}$, D. Borchman ${ }^{*}, 3$, D. Tang ${ }^{3}$ and C.A. Paterson ${ }^{3}$ \\ ${ }^{I}$ Department of Biochemistry and Molecular Biology, University of Louisville School of Medicine, Louisville, KY 40202, \\ USA \\ ${ }^{2}$ Department of Molecular, Cellular and Craniofacial Biology, University of Louisville School of Dentistry, Louisville, \\ KY 40202, USA \\ ${ }^{3}$ Department of Ophthalmology and Visual Sciences, University of Louisville School of Medicine, Louisville, KY 40202, \\ $U S A$
}

\begin{abstract}
The loss of calcium homeostasis in the lens of the eye appears to be a factor contributing to lens opacity. In the human lens, calcium homeostasis depends on the $\mathrm{Ca}^{2+}$-ATPase pumps found only in the epithelium. A plasma membrane calcium pump, PMCA2 is upregulated in human cataractous lenses. To determine if oxidation caused the plasma membrane $\mathrm{Ca}^{2+}$-ATPases (PMCA) or sarcoplasmic/endoplasmic $\mathrm{Ca}^{2+}$-ATPases (SERCA) to become upregulated, we cultured a human lens epithelial cell line, in the presence of hydrogen peroxide. We observed an increase in PMCA1, PMCA2 SERCA2b and SERCA3 mRNA levels and protein expression with increasing hydrogen peroxide concentrations and treatment times. Hydrogen peroxide caused a rise in the intracellular calcium which could be an initiating factor in the concerted upregulation of PMCA1 and SERCA3. Our data support the idea that oxidative stress could contribute to a selective rise in PMCA/SERCA expression in human cataractous lenses.
\end{abstract}

\section{INTRODUCTION}

In the lens, cellular calcium homeostasis is attained by a delicate balance between passive inward movement from the extracellular milieu through membrane channels [1], extrusion by plasma membrane calcium ATPase (PMCA) [2], sodium calcium exchange [3], and internal sequestration by sarcoplasmic/endoplasmic reticular calcium ATPase (SERCA) [4]. There are equal amounts of the PMCA and SERCA proteins in the lens [5]. In the human lens, the $\mathrm{Ca}^{2+}$-ATPase pumps are found only in the epithelium [6-9], a single layer of cells on the anterior surface beneath the lens capsule. Human lens fiber cells contain few or no intracellular organelles and no $\mathrm{Ca}^{2+}$ ATPase $[6,7,9]$. It is important to define the role of this pump in the human lens, especially in light of the study showing that $\mathrm{Ca}^{2+}$-ATPase activity is $50 \%$ lower in human cataractous lenses [6].

Oxidation is a major factor in cataract development [1015]. The lens $\mathrm{Ca}^{2+}$-ATPase pumps are very sensitive to oxidation [16-18] and oxidative inhibition of the lens $\mathrm{Ca}^{2+}$ ATPase can be reversed [18], however, inhibition of SERCA and PMCA may occur through a different mechanism $[19,20]$. Elevated intracellular calcium induces the upregulation of PMCA1 out of 4 PMCA isoforms [21], and both SERCA2 and SERCA3 [21,22] isoforms in an immortalized cell line of human lens epithelium. The oxidant hydrogen peroxide can lead to epithelial cell death and cataract [14,23-

*Address correspondence to this author at the Department of Ophthalmology and Visual Sciences, University of Louisville School of Medicine, Louisville, KY 40202, USA; E-mail: borchman@louisville.edu
26]. Hydrogen peroxide levels are elevated in both the vitreous and lens of cataractous human lenses compared to clear lenses $[27,28]$. The expression of numerous proteins [29,30], including an increase in PMCA1 [31], are altered in lens epithelial cells treated with hydrogen peroxide. The expression of SERCA is carefully controlled and changes in SERCA expression may contribute to the etiology of many diseases including Brodie's disease [32], Darier's disease [33], and heart failure [34]. Oxidative stress reduces SERCA activity [35], however, it is not known if this reduction in activity is related to a decrease in SERCA protein or mRNA levels. In human cataractous lenses PMCA2 mRNA and protein levels are elevated compared to age matched clear lenses [36]. The purpose of this study was to determine if the expression of SERCA and PMCA isoforms are changed by hydrogen peroxide.

\section{MATERIALS AND METHODOLOGY}

A human lens epithelial cell line (HLE B-3) was developed and provided by Andley et al. [37]. The human lens epithelial cells were immortalized by transfecting them with adenovirus 12-simian virus (Ad12-SV40) to maintain propagation of the cells in vitro [38]. Cell culture conditions, chemicals, membrane preparation, RNA extraction and Quantitative Real Time PCR (TagMan ${ }^{\circledR}$, applied Biosystems, Foster City, CA), Electrophoresis and Western blotting and statistical analysis were performed exactly as described in citation [21].

\section{Hydrogen Peroxide Treatment}

To study the effects of $\mathrm{H}_{2} \mathrm{O}_{2}$ as an oxidizing agent on the lens epithelial cells, at different exposure times and with 


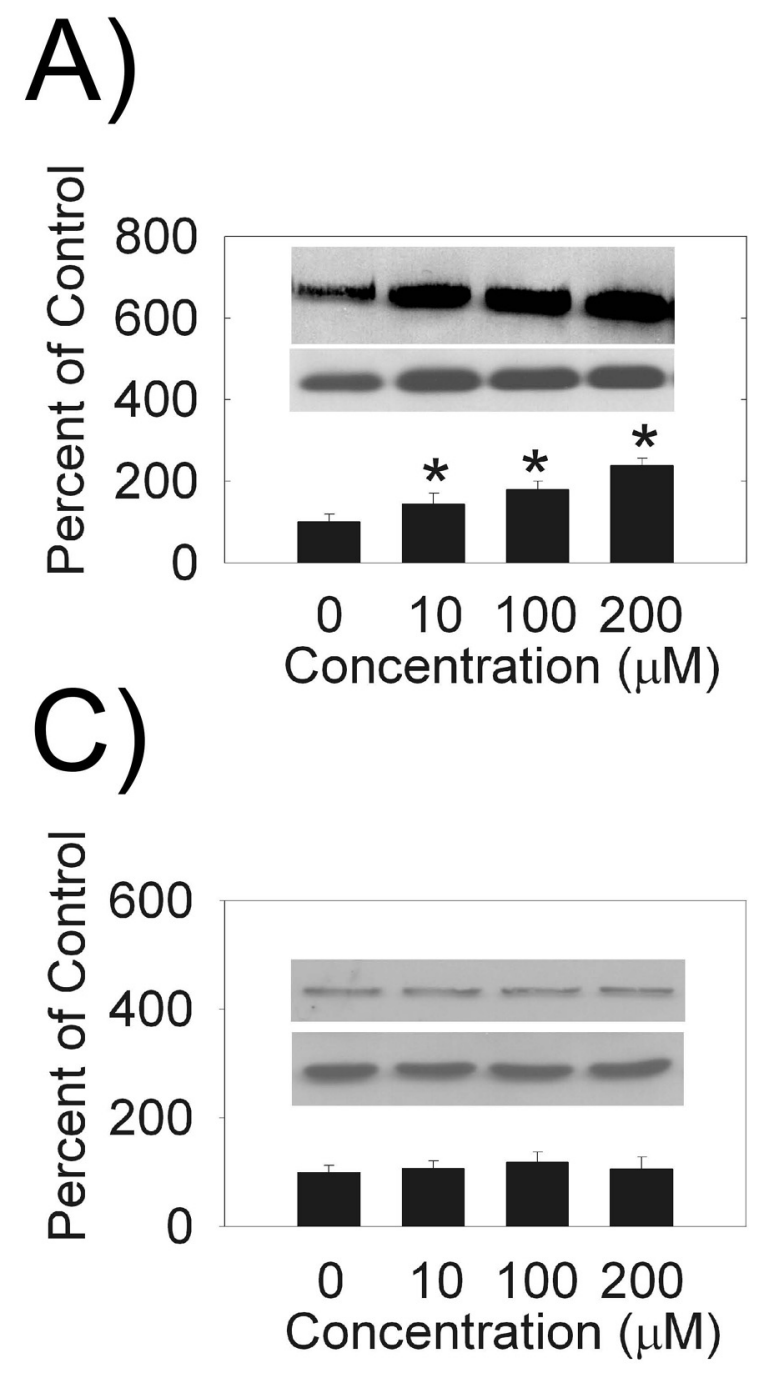

\section{B)}

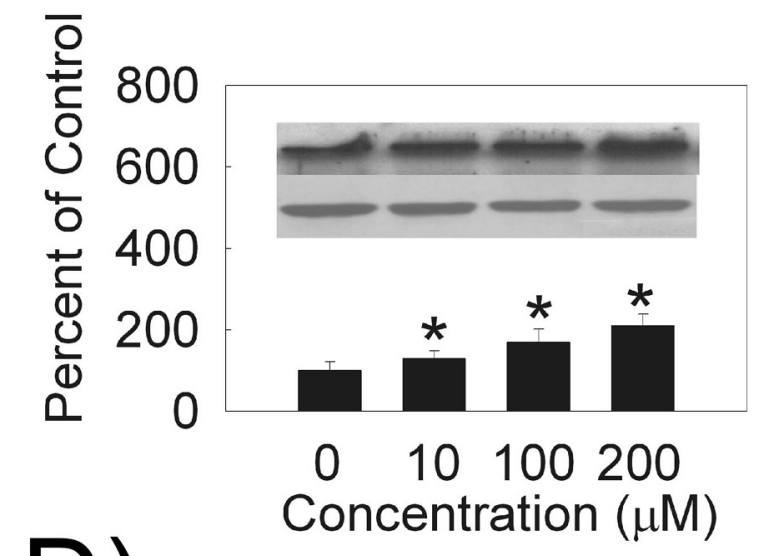

D)

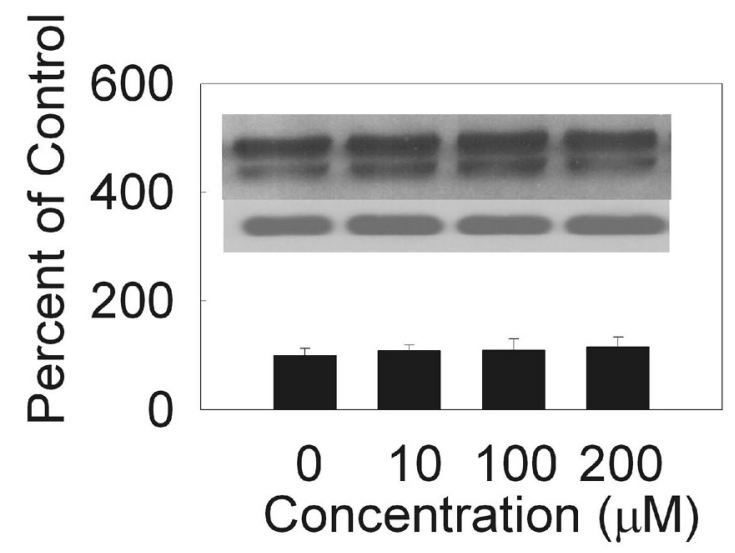

Fig. (1). Dose-dependence of hydrogen peroxide PMCA protein levels. (A) PMCA1, $130 \mathrm{kDa}(\mathbf{B}) \mathrm{PMCA} 2,120 \mathrm{kDa}(\mathbf{C}) \mathrm{PMCA} 3,134 \mathrm{kDa}$ (D) PMCA4 129 and $133 \mathrm{kDa}$. (Top Inset) A typical Western Blot showing dose-dependent effects of hydrogen peroxide on PMCA protein expression in the HLE B-3 cells treated for 4 hours. An equal amount of membrane protein was loaded in each lane and subjected to electrophoresis. Blots were incubated with a specific PMCA antibody, then stripped and reprobed with $\beta$-actin antibody (lower Western Blot insert, $42 \mathrm{kDa}$ ). (Bars) Densitometric analysis of Western Blots. Results are presented as mean \pm standard error of 3 or 4 separate experiments. A value of $\mathrm{P} \leq 0.05$ was considered significant $(*)$.

different dosages, when cells were $\sim 80 \%$ confluent, different concentrations of $\mathrm{H}_{2} \mathrm{O}_{2}$ ranging from 10 to $200 \mu \mathrm{M}$ were added to the medium and cells were cultured for 4 hours. Untreated cells were used as a control. In a separate, but similar study, the cells at $\sim 80 \%$ confluence were treated with $10 \mu \mathrm{M} \mathrm{H}_{2} \mathrm{O}_{2}$ for $4,8,16$ hours. Untreated cells were used as a control. To inhibit catalase activity, 3-aminotriazole was added to the cell culture at $20 \mathrm{mM}$ final concentration. The medium was replaced every 6 hours with fresh medium containing $10 \mu \mathrm{M} \mathrm{H}_{2} \mathrm{O}_{2}$ because $\mathrm{H}_{2} \mathrm{O}_{2}$ disappears from cell culture environment after 4 to 6 hours regardless of the presence of catalase inhibitor. Cells were analyzed microscopically with regard to their morphology and viability.

\section{Measurement of Intracellular Calcium}

Intracellular ionized calcium concentration was measured using Indo-1 AM dye [39]. Cells were grown and treated with hydrogen peroxide as in the section above. A stock solution of Indo-1 AM (2 mg/ml) was added to the cell culture medium to a final concentration of $2 \mu \mathrm{g} / \mathrm{ml}$. After a $30 \mathrm{~min}$ incubation at $37^{\circ} \mathrm{C}$ the cells were suspended with TrypsinEDTA, transferred to centrifuge tubes and centrifuged for 6 $\min$ at $180 \times \mathrm{g}, 21^{\circ} \mathrm{C}$. They were then gently washed twice, and the suspension of cells was transferred into fluorimeter cuvettes for spectroscopic analysis. Fluorescence intensity measurements were made with an ISS PC1 photon counting spectro fluorometer (Champagne, IL). Cells were stirred gently to avoid damage and to prevent them from settling. The excitation fluorescence was $346 \mathrm{~nm}$ and the emission fluorescence intensity was measured at $400 \mathrm{~nm}$ and $475 \mathrm{~nm}$. Fluorescence intensities were corrected for the baseline. The fluorescence intensity ratio $\mathrm{I}_{400} / \mathrm{I}_{475}$ was used to estimate changes in ionized calcium concentration.

\section{RESULTS}

We examined the effects of hydrogen peroxide on the expression of PMCA and SERCA isoforms in HLE B-3 cells. We observed an increase in PMCA1 (Fig. 1A), 


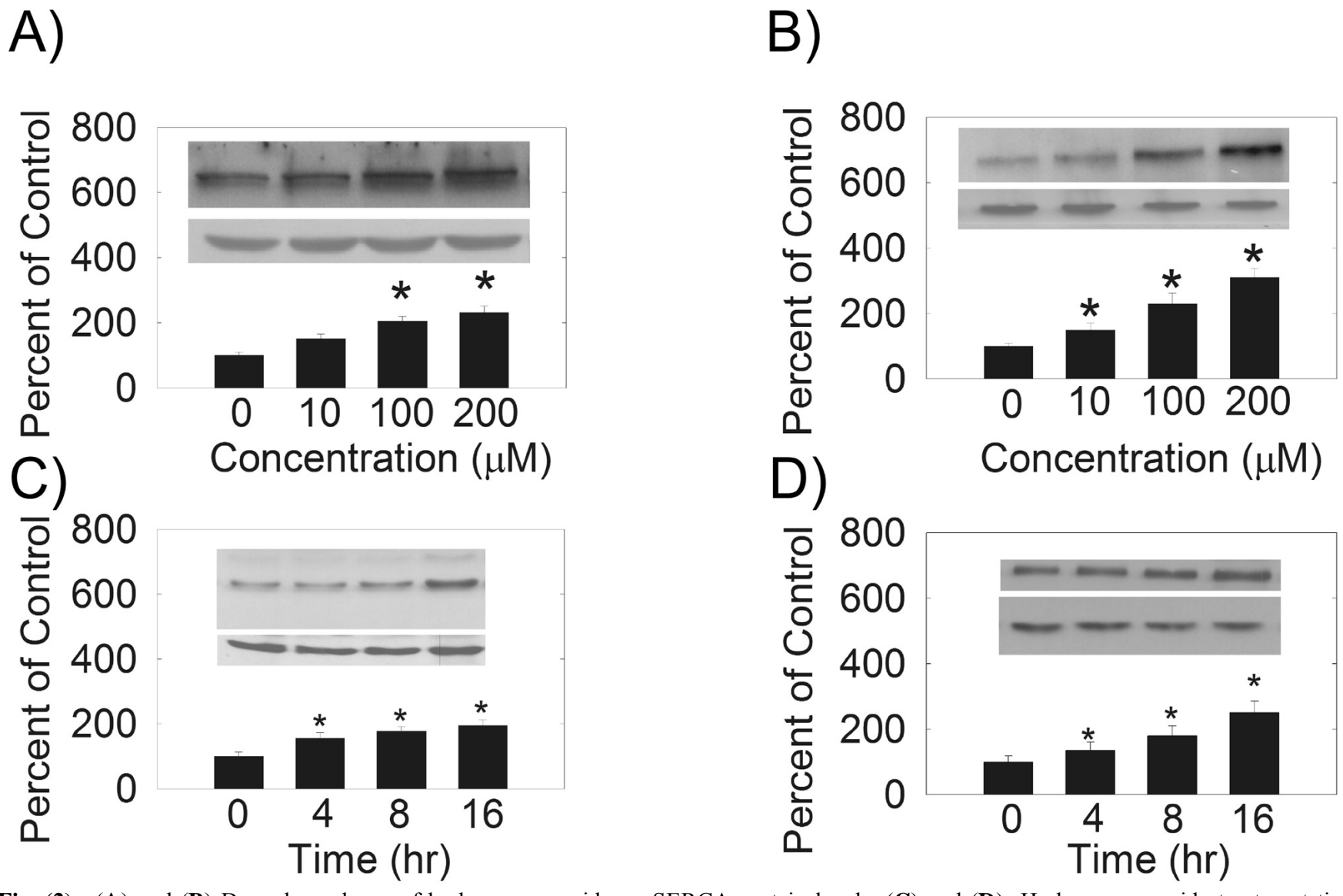

Fig. (2). (A) and (B) Dose-dependence of hydrogen peroxide on SERCA protein levels. (C) and (D) Hydrogen peroxide treatment time dependence of SERCA protein levels. (Top Inset) A typical Western Blot showing time-dependent effects of $10 \mu \mathrm{M}$ hydrogen peroxide on SERCA protein expression in the HLE B-3 cells. An equal amount of membrane protein was loaded in each lane and subjected to electrophoresis. A and C) SERCA2, 100-105 kDa, B and D) SERCA3, $97 \mathrm{kDa}$. Blots were incubated with a specific SERCA antibody, then stripped and reprobed with $\beta$-actin antibody antibody (lower Western Blot insert, $42 \mathrm{kDa}$ ). (Bars) Densitometric analysis of Western Blots.

PMCA2 (Fig. 1B), SERCA2 (Fig. 2A) and SERCA3 (Fig. 2B) levels with increasing hydrogen peroxide concentration. Quantification of PMCA1, PMCA2, SERCA2 and SERCA3 mRNA by quantitative real time RT-PCR (Table 1) also showed a does-dependent increase in the mRNA levels. There were no differences between the expression of protein, or mRNA, for PMCA3 or PMCA4 (Figs. 1C,D, Table 1).

In a similar study, we evaluated the effects of hydrogen peroxide on the PMCA and SERCA protein and mRNA levels at different treatment times by both Western blot (Figs. 2C,D and Fig. 3) and quantitative real time RT-PCR techniques (Table 1). Densitometric analysis of the protein bands showed that PMCA1 (Fig. 3A), PMCA2 (Fig. 3B), SERCA2 (Fig. 2C) and SERCA3 (Fig. 2D) protein levels were significantly increased with $10 \mu \mathrm{M}$ hydrogen peroxide treatment in a time- dependent manner. The quantification of the level of mRNA by real time RT-PCR showed that after 4,8 , and 16 hours of hydrogen peroxide treatment, the levels of PMCA1, PMCA2, SERCA2 and SERCA3 mRNA increased significantly (Table 1). The levels of PMCA3 and PMCA4 protein and mRNA did not change with treatment time (Table 1).

Cell calcium increased after 4 hours of hydrogen peroxide treatment (Fig. 4). The increase in cell calcium with hydrogen peroxide was concentration dependent and could be fit (Sigma Plot 8.0, SPSS, Inc., Chicago IL) to a four-parameter logistic equation used to measure ligand binding $\left(r^{2}=0.944\right)$.

\section{DISCUSSION}

To evaluate the effects of oxidation on lens epithelial cell PMCA and SERCA expression, we used a cell line derived from human lens epithelial cells, HLE B-3. In this study, we have shown that hydrogen peroxide treatment of HLE B-3 cells upregulates PMCA1, PMCA2 and SERCA2 and SERCA3 in a dose- and time-dependent manner while the PMCA3 and PMCA4 expression remained unchanged. In the present study, we treated the HLE B-3 cells with hydrogen peroxide to evaluate the responses of these cells to oxidative stress. The concentration of hydrogen peroxide used in these studies was in the range $10-200 \mu \mathrm{M}$ which is only slightly higher than the hydrogen peroxide concentrations found in human cataract 1-75 $\mu \mathrm{M}[27,28]$. Higher concentrations of hydrogen peroxide $(>200 \mu \mathrm{M})$ caused a fraction of cells to die. Wang et al. [40] found that $50 \%$ of the HLE B-3 cells were not viable after 8 hours of treatment with $100 \mu \mathrm{M}$ hydrogen peroxide due to the loss of mitochondrial function. We did not use "conditioned cells" that have been generated by gradually exposing the cells to higher concentrations of peroxides which causes the cells to survive in higher concentrations of peroxides compared to control cells [29]. These cells develop a complex antioxidant defense system which is comprised of high concentrations of catalase, gluthation-Stransferase and regulators of metal ion concentration, such as ferritin and hephaestin. 
A)

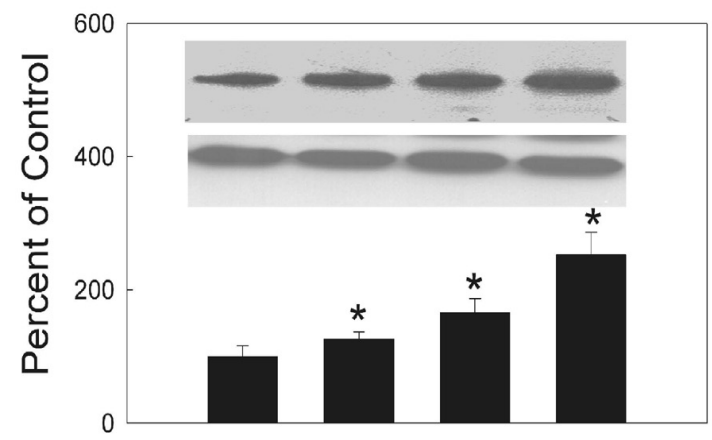

0

( )

4

8

Time (h)

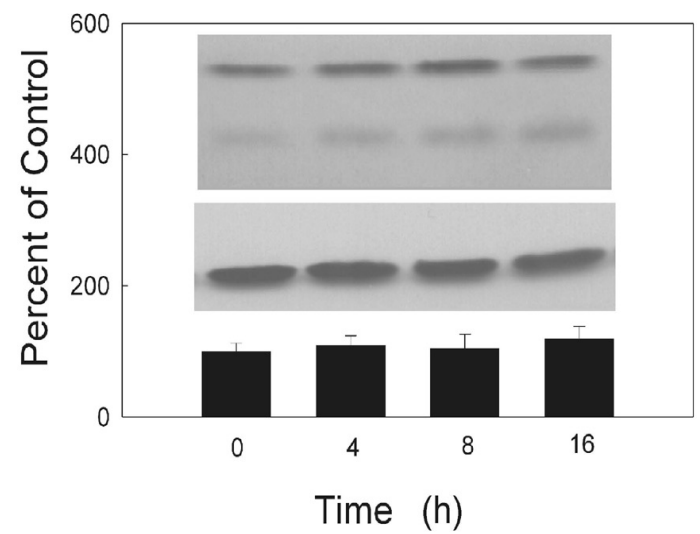

B)
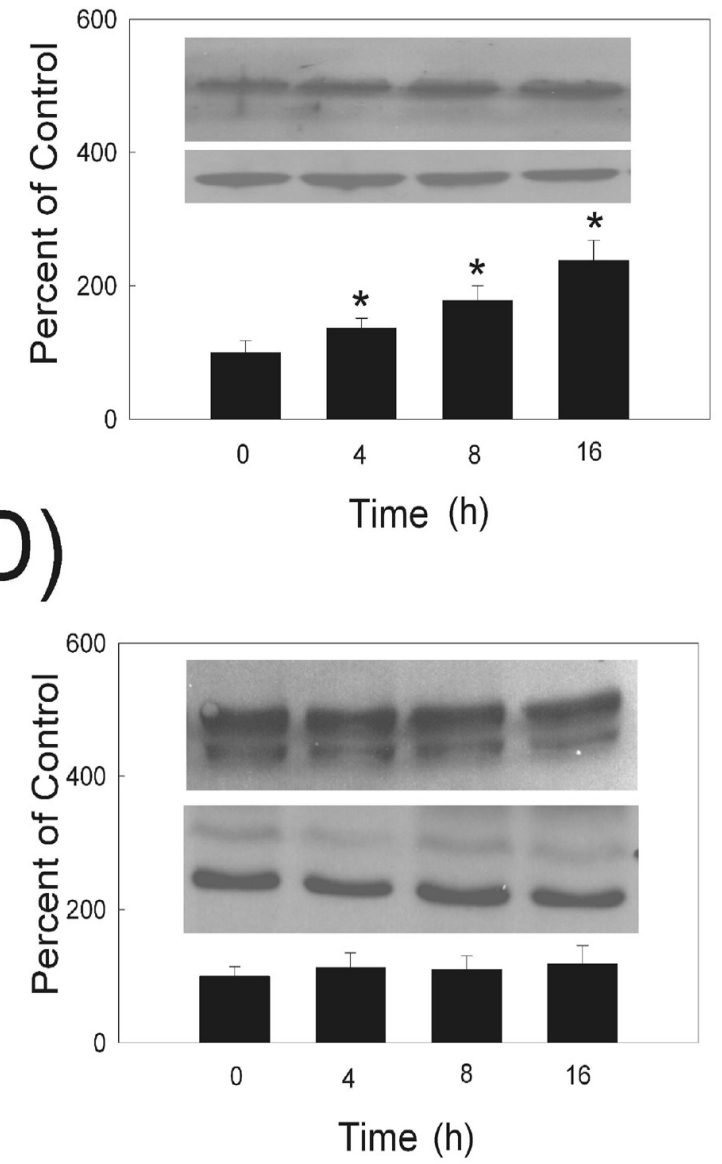

Fig. (3). Hydrogen peroxide treatment time dependence of PMCA protein levels. (Top Inset) A typical Western Blot showing timedependent effects of $10 \mu \mathrm{M}$ hydrogen peroxide on PMCA protein expression in the HLE B-3 cells. (A) PMCA1, 130 kDa (B) PMCA2, 120 $\mathrm{kDa}(\mathbf{C})$ PMCA3, $134 \mathrm{kDa}$ (D) PMCA4 129 and $133 \mathrm{kDa}$. An equal amount of membrane protein was loaded in each lane and subjected to electrophoresis. Blots were incubated with a specific PMCA antibody, then stripped and reprobed with $\beta$-actin antibody antibody (lower Western Blot insert, $42 \mathrm{kDa}$ ). (Bars) Densitometric analysis of Western Blots. Results are presented as mean \pm standard error of 3 or 4 separate experiments. A value of $\mathrm{P} \leq 0.05$ was considered significant $\left(^{*}\right)$.

In our study, $\beta$-actin was used as an internal control for protein expression and GAPDH was used as an internal control for mRNA. The expression of $\beta$-actin may be influenced by $\mathrm{H}_{2} \mathrm{O}_{2}$ treatment [41]. Because the results for both mRNA and protein expression were consistent, the possibility that the controls were influenced by $\mathrm{H}_{2} \mathrm{O}_{2}$ is not likely.

Why do human lens epithelial cells have such a profound response to the oxidative stress which is manifested by a significant increase in the expression of calcium regulatory proteins, PMCA1, PMCA2, SERCA2 and SERCA3? The normal electrolyte composition of the healthy lens is achieved by the balance between passive ion leakage and active transport. Both aspects of ion regulation are compromised when the lens is exposed to hydrogen peroxide [42]. Electrophysiological experiments have shown that shortly after exposing the lens to hydrogen peroxide, there was a significant increase in the lens passive permeability and a partial impairment of the lens $\mathrm{Na} / \mathrm{K}$ - pump [42]. The sensi- tivity of the lens transport pumps to the concentration of hydrogen peroxide changes abruptly around $100 \mu \mathrm{M}$. Lower concentrations have less effect on the ion transport pumps and lens ion content [42] probably because, high concentration of hydrogen peroxide $(>60 \mu \mathrm{M})$ overwhelm the antioxidant protection system of the lens [43].

The sum of lens SERCA and PMCA activity is substantially inhibited by $\mu \mathrm{M}$ levels of hydrogen peroxide $[18,44]$ and in light of our findings, we speculate that hydrogen peroxide inhibits the calcium pumps in HLE B-3 cells. After treating HLE B-3 cells for 3 hours with $125 \mu \mathrm{M}$ hydrogen peroxide, calcium influx doubled as a result of $\mathrm{Ca}^{2+}$-ATPase inhibition or increased membrane permeability [45]. PMCA1 was one of many proteins upregulated in HLE B-3 cells that were conditioned to withstand high levels of peroxide [46] in agreement with the present study. The fact that PMCA1 and SERCA3 are upregulated by hydrogen peroxide treatment as well as by increased intracellular calcium levels after thapsi- 
Table 1. PMCA and SERCA mRNA Expression Versus Treatment Time and $\mathrm{H}_{2} \mathrm{O}_{2}$ Concentration

\begin{tabular}{|c||c|c|c|c|c|c|}
\hline & $\mathbf{4 h r}, \mathbf{1 0} \boldsymbol{\mu M}$ & $\mathbf{8} \mathbf{h r}, \mathbf{1 0} \boldsymbol{\mu M}$ & $\mathbf{1 6} \mathbf{h r}, \mathbf{1 0} \boldsymbol{\mu M}$ & $\mathbf{4} \mathbf{~ h r}, \mathbf{1 0} \boldsymbol{\mu M}$ & $\mathbf{4} \mathbf{h r}, \mathbf{1 0 0} \boldsymbol{\mu M}$ & $\mathbf{4} \mathbf{h r}, \mathbf{2 0 0} \boldsymbol{\mu M}$ \\
\hline \hline PMCA1 mRNA & $1.8 \pm 0.2$ & $2.2 \pm 0.3$ & $3.3 \pm 0.3$ & $1.8 \pm 0.3$ & $2.4 \pm 0.2$ & $3.0 \pm 0.3$ \\
\hline PMCA2 mRNA & $1.5 \pm 0.2$ & $2.0 \pm 0.3$ & $2.5 \pm 0.2$ & $1.6 \pm 0.1$ & $2.0 \pm 0.2$ & $2.9 \pm 0.3$ \\
\hline PMCA3 mRNA & $1.1 \pm 0.2$ & $1.2 \pm 0.2$ & $1.2 \pm 0.1$ & $1.2 \pm 0.2$ & $1.2 \pm 0.2$ & $1.3 \pm 0.3$ \\
\hline PMCA4 mRNA & $1.1 \pm 0.2$ & $1.1 \pm 0.2$ & $1.2 \pm 0.2$ & $1.1 \pm 0.2$ & $1.1 \pm 0.2$ & $1.2 \pm 0.2$ \\
\hline SERCA2 mRNA & $1.5 \pm 0.2$ & $2.1 \pm 0.2$ & $2.9 \pm 0.3$ & $1.9 \pm 0.2$ & $2.4 \pm 0.3$ & $3.4 \pm 0.3$ \\
\hline SERCA3 mRNA & $1.6 \pm 0.3$ & $2.0 \pm 0.2$ & $3.1 \pm 0.3$ & $1.8 \pm 0.3$ & $3.0 \pm 0.3$ & $3.4 \pm 0.4$ \\
\hline
\end{tabular}

PMCA1 and 2 and SERCA 2 and 3 are statistically different, $\mathrm{p}<0.05$.

Data are average \pm standard error of the mean, $n=3-4$.

gargin treatment [21] or hydrogen peroxide treatment [45] indicates a concerted effort by the cells to overcome a deleterious peroxide-induced increase in calcium. Thus, oxidationinduced elevated calcium levels may be an initiating factor in the concerted upregulation of PMCA1 and SERCA3 [22].

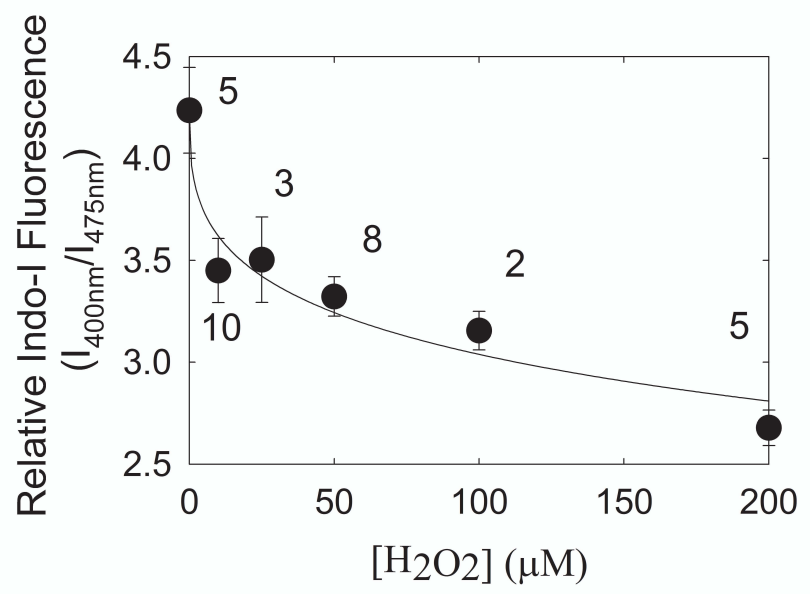

Fig. (4). HLE B-3 cells were treated with hydrogen peroxide for 4 hours and the ratio of the fluorescence intensity of the calcium probe Indo-1 AM was used to measure changes in ionized intracellular calcium. A drop in the level of $\mathrm{I}_{400} / \mathrm{I}_{475}$ indicates hydrogen peroxide treatment caused intracellular calcium to rise. We estimate that calcium rose from $120 \mathrm{nM}$ to $160 \mathrm{nM}$ with $200 \mu \mathrm{M} \mathrm{H}_{2} \mathrm{O}_{2}$ treatment. Data are presented as mean \pm standard error. Numbers next to the data points are the number of separate experiments

The fact that PMCA2 was upregulated in human cataractous lenses [36] and in hydrogen peroxide treated HLE B-3 cells in this study, but not by thapsigargin [21], a plant derived natural compound that inhibits SERCA and elevates intracellular calcium, points to regulatory factors for PMCA2 other than calcium. Similarly, SERCA2 is upregulated with $\mathrm{H}_{2} \mathrm{O}_{2}$ treatment, but not up regulated by a thapsigargin induced increase in intracellular calcium. What the regulatory factors regulate are and whether other stresses regulate calcium pump expression remains to be determined. In previous studies $[8,21,22]$ we made the assumption that we were measuring the protein expression of SERCA2b since this alternatively spliced isoform is expressed in all cell types and SERCA2a has been found only in muscle tissue. Until this assumption is tested with antibodies specific for
SERCA2 $a$ and SERCA2 $b$, we refrained from making the distinction between the alternatively spliced isoforms, a and $\mathrm{b}$, of SERCA2. The $120 \mathrm{bp}$ nucleotides sequence that we used for quantitative real time PCR is specific for SERCA2b mRNA [22] and the partial sequence of the $270 \mathrm{bp}$ fragment from SERCA2b PCR product is $100 \%$ homologus to the sequence encoded region from 2864-2983 bp of the human SERCA2b gene (M23115) [22]. In this study, mRNA specific for SERCA2b and protein expression for SERCA2 follow similar patterns of expression.

Why PMCA1 and PMCA2 are upregulated by hydrogen peroxide treatment and PMCA3 and PMCA4 are not is a difficult question to answer. PMCA isoform diversity, function and distribution have been reviewed [47]. As pointed out in the review [47], determining the function of individual isoforms is extremely difficult because usually more than one isoform is expressed in a tissue and there are no inhibitors specific for any of the PMCA isoforms or splice variants. Compared to PMCA4, PMCA2 is active at lower calcium, ATP and calmodulin concentrations [47-49], so in an oxidatively stressed cell with a low ATP concentration, expression or PMCA would be advantageous over the expression of PMCA4. Another advantage of selectively upregulating PMCA2 rather than PMCA3 is that PMCA2 has a 50 fold higher affinity for calmodulin than PMCA3 which is virtually a calmodulin-independent pump [47,50]. A complication to these speculations is that we did not quantify the over 30 splice variants of the PMCA's and alternative splicing can impact the function of a PMCA isoform. For instance compared to the $b$ splice form, the a splice form exhibits lower calmodulin binding and activation, lower calcium affinity and lower protein kinase $\mathrm{C}$ phosphorylation $[47,49]$.

\section{CONCLUSIONS}

Under a wide range of treatment times and concentrations used in this study, $\mathrm{H}_{2} \mathrm{O}_{2}$ did not decrease the expression of any of the $\mathrm{Ca}^{2+}$-ATPase isoforms measured, and for some isoforms, the expression of $\mathrm{Ca}^{2+}$-ATPase increased. The upregulation of SERCA after 4 hours of $\mathrm{H}_{2} \mathrm{O}_{2}$ treatment indicates that $\mathrm{Ca}^{2+}$-ATPase activity measurements in human lenses need to be interpreted cautiously since human lenses are often collected 4-24 hours post mortem. Our data suggest that oxidative stress could contribute to the rise in the level of PMCA2 expression in human cataractous lenses compared with age matched clear lenses [36]. 


\section{ACKNOWLEDGEMENTS}

Supported by USPH research grant EY06916, the Kentucky Lions Eye Foundation, an unrestricted grant from Research to Prevent Blindness Inc.

\section{REFERENCES}

[1] Cooper KE, Tang JM, Rae JL, Eisenberg RS. A cation channel in frog lens epithelia responsive to pressure and calcium. J Mem Biol 1986; 93: 259-69.

[2] Hightower KR, Kinsey VE. Transport and bioelectric properties of post-mortem lenses. Exp Eye Res 1980; 30: 19-28.

[3] Tomlinson DR, Willars GB, Calcutt NA, et al. Effects of sorbinil treatment in rats with chronic streptozotocin-diabetes; changes in lens and in substance $\mathrm{P}$ and catecholamines in the iris. Curr Eye Res 1989; 8: 357-63.

[4] Duncan G, Webb SF, Dawson AP, Bootman MD, Elliott AJ. Calcium regulation in tissue-cultured human and bovine lens epithelial cells. Invest Ophthalmol Vis Sci 1993; 34: 2835-42.

[5] Zeng J, Borchman D, Paterson CA. ATPase activities of rabbit and bovine lens epithelial microsomes: a continuous fluorimetric assay study. Curr Eye Res 1995; 14: 87-93.

[6] Paterson CA, Zeng J, Husseini Z, et al. Calcium ATPase activity and membrane structure in clear and cataractous human lenses. Curr Eye Res 1997; 16: 333-8.

[7] Borchman D, Paterson CA, Delamere NA. Ca ${ }^{2+}$-ATPase activity in the human lens. Curr Eye Res 1989; 8: 1049-54.

[8] Liu L, Bian L, Borchman D, Paterson CA. Expression of sarco/endoplasmic reticular $\mathrm{Ca}^{2+}$-ATPase in human lens epithelial cells and cultured human lens epithelial B-3 cells. Curr Eye Res 1999; 19: 389-94.

[9] Marian MJ, Li H, Borchman D, Paterson CA. Plasma membrane $\mathrm{Ca}^{2+}$-ATPase expression in the human lens. Exp Eye Res 2005; 81: 57-64.

[10] Babizhayev MA, Deyev AI, Linberg LF. Lipid peroxidation as a possible cause of cataract. Mech Ageing Develop 1988; 44: 69-89.

[11] Giblin FJ. Glutathione: a vital lens antioxidant. J Ocul Pharmacol Therap 2000; 16: 121-35.

[12] Lou MF. Redox regulation in the lens. Prog Retin Eye Res 2003; 22: 657-682.

[13] Spector A. The search for a solution to senile cataracts. Proctor lecture, Invest Ophthalmol Vis Sci 1984; 25: 130-46.

[14] Spector A. Oxidative stress-induced cataract: mechanism of action. FASEB J 1995; 9: 1173-82.

[15] Zigler J, Hess HH. Cataracts in the Royal College of Surgeons rat: evidence for initiation by lipid peroxidation products. Exp Eye Res 1985; 41: 67-76.

[16] Borchman D, Paterson CA, Delamere NA. Oxidative inhibition of $\mathrm{Ca}^{2+}$-ATPase in the rabbit lens. Invest Ophthalmol Vis Sci 1989; 30: 1633-7.

[17] Borchman D, Paterson CA, Delamere N. Selective inhibition of membrane ATPases by hydrogen peroxide in the lens of the eye. Basic Life Sci 1988; 49: 1029-33.

[18] Ahuja RP, Borchman D, Dean WL, et al. Effect of oxidation on $\mathrm{Ca}^{2+}$-ATPase activity and membrane lipids in lens epithelial microsomes. Free Rad Biol Med 1999; 27: 177-85.

[19] Redondo PC, Salido GM, Rosado JA, Pariente JA. Effect of hydrogen peroxide on $\mathrm{Ca}^{2+}$ mobilisation in human platelets through sulphydryl oxidation dependent and independent mechanisms. Biochem Pharmacol 2004; 67: 491-502.

[20] Zaidi A, Barron L, Sharov VS, Schoneich C, Michaelis EK, Michaelis ML. Oxidative inactivation of purified plasma membrane $\mathrm{Ca}^{2+}$-ATPase by hydrogen peroxide and protection by calmodulin. Biochemistry 2003; 42: 12001-10.

[21] Marian MJ, Mukhopadhyay P, Borchman D, Paterson CA. Regulation of PMCA and SERCA expression in cultured human lens epithelial cells with calcium. Cell Calcium 2007; 41: 87-95.

[22] Liu L, Paterson CA, Borchman D. Regulation of sarco/endoplasmic $\mathrm{Ca}^{2+}$-ATPase expression by calcium in human lens cells. Exp Eye Res 2002; 75: 583-90.
[23] Spector A, Kuszak JR, Ma W, Wang RR, Ho Y, YangY. The effect of photochemical stress upon the lenses of normal and glutathione peroxidase-1 knockout mice. Exp Eye Res 1998; 67: 457-71.

[24] Spector A, Ma W, Wang RR. The aqueous humor is capable of generating and degrading $\mathrm{H}_{2} \mathrm{O}_{2}$. Invest Ophthalmol Vis Sci 1998; 39: 1188-97.

[25] Spector A, Wang GM, Wang RR, Garner WH, Moll H. The prevention of cataract caused by oxidative stress in cultured rat lenses. I. $\mathrm{H}_{2} \mathrm{O}_{2}$ and photochemically induced cataract. Curr Eye Res 1993; 12: 163-79.

[26] Giblin FJ, McCready JP, Schrimscher L, Reddy VN. Peroxideinduced effects on lens cation transport following inhibition of glutathione reductase activity in vitro. Exp Eye Res 1987; 45: 77-91.

[27] Spector A, Garner WH. Hydrogen peroxide and human cataract. Exp Eye Res 1981; 33: 673-81.

[28] Devamanoharan PS, Ramachandran S, Varma SD. Hydrogen peroxide in the eye lens: radioisotopic determination. Curr Eye Res 1991; 10: 831-8.

[29] Ma W, Kleiman NJ, Sun F, Li D, Spector A. Peroxide toxicity in conditioned lens epithelial cells--evaluation of multi-defense systems. Exp Eye Res 2003; 77: 711-20.

[30] Goswami S, Sheets NL, Zavadil J, et al. Spectrum and range of oxidative stress responses of human lens epithelial cells to $\mathrm{H}_{2} \mathrm{O}_{2}$ Insult. Invest Ophthalmol Vis Sci 2003; 44: 2084-93.

[31] Ma W, Li D, Sun F, Spector A. Comparison of characteristics of peroxide-conditioned immortal human lens-epithelial cell lines with their murine counterparts. Exp Eye Res 2004; 79: 411-7.

[32] Odermatt A, Taschner PE, Khanna VK, et al. Mutations in the gene-encoding SERCA1, the fast-twitch skeletal muscle sarcoplasmic reticulum $\mathrm{Ca}^{2+}$ - ATPase, are associated with Brody disease. Nat Genet 1996; 14: 191-4.

[33] Sakuntabhai A, Ruiz-Perez V, Carter S, et al. Mutations in ATP2A2, encoding a $\mathrm{Ca}^{2+}$ pump, cause Darier disease. Nat Genet 1999; 21: 271-7.

[34] Misquitta CM, Mack DP, Grover AK. Sarco/endoplasmic reticulum $\mathrm{Ca}^{2+}$ (SERCA)-pumps: link to heart beats and calcium waves. Cell Calcium 1999; 25: 277-90.

[35] Schoneich C. Reactive oxygen species and biological aging: a mechanistic approach. Exp Gerontol 1999; 34: 19-34.

[36] Marian MJ. Plasma Membrane -ATPase Expression in the Human Lens with Age and Cataract. Ophthtalmic Res 2008; 40: 86-93.

[37] Andley UP, Rhim JS, Chylack LT Jr., Fleming TP. Propagation and immortalization of human lens epithelial cells in culture. Invest Ophthalmol Vis Sci 1994; 35: 3094-102.

[38] Zeitlin PL, Lu L, Rhim J, et al. A cystic fibrosis bronchial epithelial cell line: immortalization by adeno-12-SV40 infection. Am J Resp Cell Mol Biol 1991; 4: 313-9.

[39] O'Brien PJ. Calcium sequestration by isolated sarcoplasmic reticulum: real-time monitoring using ratiometric dual-emission spectrofluorometry and the fluorescent calcium-binding dye indo-1. Mol Cell Biochem 1990; 94: 113-9.

[40] Wang X, Simpkins JW, Dykens JA, Cammarata PR. Oxidative damage to human lens epithelial cells in culture: estrogen protection of mitochondrial potential, ATP, and cell viability. Invest Ophthalmol Vis Sci 2003; 44: 2067-75.

[41] Courgeon AM, Rollet E, Becker J, Maisonhaute C, Best-Belpomme M. Hydrogen peroxide $\left(\mathrm{H}_{2} \mathrm{O}_{2}\right)$ induces actin and some heat-shock proteins in Drosophila cells. Eur J Biochem 1988; 171: 163-70.

[42] Delamere NA, Paterson CA, Borchman DB, Hensley SK. Alteration of lens electrolyte transport parameters following transient oxidative perturbation. Curr Eye Res 1988; 7: 969-79.

[43] Giblin FJ, McCready JP. The effect of inhibition of glutathione reductase on the detoxification of $\mathrm{H}_{2} \mathrm{O}_{2}$ by rabbit lens. Invest Ophthalmol Vis Sci 1983; $24: 113-8$

[44] Zhang Z, Zeng J, Yin H, Tang D, Borchman D, Paterson CA. Membrane lipid alpha-crystallin interaction and membrane $\mathrm{Ca}^{2+}$. ATPase activities. Curr Eye Res 1999; 18: 56-61.

[45] Spector A, Wang RR, Ma W, Kleiman NJ. Development and characterization of an $\mathrm{H}_{2} \mathrm{O}_{2}$-resistant immortal lens epithelial cell line. Invest Ophthalmol Vis Sci 2000; 41: 832-43. 
[46] Ma W, Li D, Sun F, Spector A. Comparison of characteristics of peroxide-conditioned immortal human lens-epithelial cell lines with their murine counterparts. Exp Eye Res 2004; 79: 411-7.

[47] Strehler EE, Zacharias DA. Role of alternative splicing in generating isoform diversity among plasma membrane calcium pumps. Physiol Rev 2001; 81: 21-190.

[48] Elwess NL, Filoteo AG, Enyedi A. Plasma membrane $\mathrm{Ca}^{2+}$ pump isoforms $2 \mathrm{a}$ and $2 \mathrm{~b}$ are unusually responsive to calmodulin and $\mathrm{Ca}^{2+}$. J Biol Chem 1997; 272: 17981-6.
[49] Hilfiker H, Guerini D, Carafoli E. Cloning and expression of isoform 2 of the human membrane $\mathrm{Ca}^{2+}$-ATPase. J Biol Chem 1994; 269: 26178-203.

[50] Filoteo AG, Enyedi A, Verma AK, Elwess NL, Penniston JT Plasma membrane $\mathrm{Ca}^{2+}$ pump isoform $3 \mathrm{f}$ is weakly stimulated by calmodulin. J Biol Chem 2000; 275: 4323-8.

Received: April 25, 2008

Revised: June 9, 2008

Accepted: June 17, 2008

(C) Marian et al.; Licensee Bentham Open.

This is an open access article distributed under the terms of the Creative Commons Attribution License (http://creativecommons.org/licenses/by/2.5/), which permits unrestrictive use, distribution, and reproduction in any medium, provided the original work is properly cited. 